\title{
Managed attenuation of the mining enterprise as a component of the development strategy of the territory
}

\author{
Dmitriy Yadransky ${ }^{1}$,Elena Chumak $^{2 *}$ and Rinat Latypov ${ }^{3}$ \\ ${ }^{1}$ Ural State Mining University, Department of Economics and Management, 620144, Yekaterinburg, \\ Russian Federation \\ ${ }^{2}$ Ural State University of Economics, Department of Management and Entrepreneurship, 620000, \\ Yekaterinburg, Russian Federation \\ ${ }^{3}$ Ural State University of Economics, Department of State and Municipal Administration, 620000, \\ Yekaterinburg, Russian Federation
}

\begin{abstract}
The article critically examines the positive and negative consequences of labor productivity growth at mining enterprises in the conditions of the old industrial region. It is suggested that for enterprises of the middle Urals it is necessary to form a mining production development strategy based on the directions of the regional strategy, which is not always connected with labor productivity growth by increasing mining volumes. The article is aimed at studying the factors affecting the prospects of mining enterprises activity from the standpoint of choosing strategic alternatives to their development. The methods of analysis: logical analysis, structural analysis, logical modeling, literature analysis. Using the logical modeling method, the following hypothesis was verified: that mining enterprises strategic development features in the conditions of an old industrial region should consider the strategy of municipalities in which these enterprises are located. For such mining enterprises, the increase in productivity through increased production is not unequivocally positive. It is concluded that in order to ensure the activities coherence of regions and enterprises, it is necessary to ensure balanced development, which can be achieved through the application of a managed strategy attenuation of the mining enterprise.
\end{abstract}

\section{Introduction}

Considering the issue of the mining enterprises influence on the territories development it is possible to state that their role is gradually weakening. It should be noted that most of the mining enterprises of the middle Urals are located on the old (aging) mineral and raw materials base. In recent years, this trend is typical for several post-Soviet countries. In this sense, quite indicative is the experience of Ukraine in Donetsk coal and Kryvorozhsky iron ore basins. The situation there has become not only the object of scientific discussion, but also part of the state policy (to support the extractive industry). Russian authors note that the performance indicators of mining enterprises show a stable position of the industry (in 2010 - 2012 and in the near future), but at the same time they reveal insufficient work to modernize fixed assets and improve the productivity of quarries' mining equipment [1]. The

\footnotetext{
* Corresponding author: lena22021977@yandex.ru
} 
same researchers also find certain negative traits (but within the sphere of iron ore mining), noting that in the iron ore sub-industry there is a negative trend in output commodity products decline due to the quality deterioration of mined crude ore [1]. The resulting deficit is covered mainly by supplies from Kazakhstan (SSGPO OJSC) in the amount of 9-10.5 million $t /$ year [2]. The described situation shows that domestic metallurgical enterprises do not have sufficient commodity diversification, and they are accordingly located in the zone of potential risk. It is important to mention that for the middle Urals mining and metallurgical enterprises often perform the city-forming role, which requires special attention to the prospects of their development.

Analyzing the situation prevailing in Ukraine (especially in the coal industry) Ukrainian researchers note that in their opinion for the next 15-20 years it is rational to phase out lossmaking enterprises of the industry. This requires a balanced and careful approach, as well as a significant cost, including addressing complex social and environmental problems. According to the authors, the main efforts should be directed at managing the production resources of mines, which still have economic potential and are provided with relatively high-quality reserves for 15-20 years [3]. However, this approach is focused only on meeting the interests of mining enterprises without considering the development peculiarities of the metallurgical industry and individual cities (regions).

\section{Materials and methods}

Thus, it is possible to formulate the issue for this article - systematically consider the group of factors influencing the development prospects of mining enterprises from the perspective of choosing strategic alternatives to their development. The main methods of analysis: logical analysis, structural analysis, logical modeling, literature analysis. Through logical modeling it is proposed to verify the hypothesis that in case of lack of strategic prospects for a mining enterprise in the old industrial region the most effective is the mining enterprise managed attenuation strategy. With this, we consider the term of active working life of the generation (i.e. about 20 years for a mining enterprise) as strategic prospects, which is also connected with the the enterprise labor resources provision. This strategy should be part of the municipal development plan, since the mining enterprise liquidation carries not only social but also environmental consequences.

\section{Discussions}

According to classical approaches, which have not lost their principal relevance in modern literature, tools for solving efficiency increase problems of the mining enterprise are the tools already specified by A. Shpitalnikov (in the $60 \mathrm{~s}$ of the previous century). The following is referred to them by the author:

- technical progress - qualitative improvement of mechanization and automation level, as well as bringing the technology in line with new mechanization;

- production volumes increase, mainly due to the reduction of mine stripping.

- increasing the concentration of mining operations and increasing the mining intensification;

- improving the production and labor organization and production management organization;

- improving the structure of fixed production funds by increasing the equipment share and utilization rates of fixed production funds. [4].

In the current economic and organizational and technical conditions, none of the listed tools for mining enterprises located in the old industrial regions is practically applicable. 
The fourth indicator's effectiveness requires a separate explanation, but we note that there are no real tools to improve this indicator and effective influence mechanisms of municipal authorities on the development strategy of the mining enterprise.

In parallel, as its operating time increases, any aging mining enterprise has a linearly increasing number of economic difficulties. It should be noted that this problem manifests itself in several contexts:

- at higher mining depth - growing mine stripping volume (with the consequent problems of transportation and storage of gangue);

- when attempting associated extraction, the number (volume) of tailings increases;

- in the attempt to save material resources (including consumables) industrial injuries increase, which ultimately leads to the reduction of labor resources;

- when trying to save on human resources - their outflow to other regions begins, leading to local labor depletion. The profession prestige is also falling, leading to a reduction in the flow of skilled personnel to the industry (group of enterprises).

The list of the problems cited is not exhaustive and can be continued. However, the list makes it possible to state that the regional socio-economic utility from mining enterprise development cannot be estimated only through the indicators of the current economic feasibility. Separately taken indicators of environmental consequences also do not allow to reliably assess the correctness of the strategy choice of the mining enterprise for the municipality development.

Consistency of mining enterprises problems is related to the fact that in the process of mining there are also related complications in addition to direct environmental ones. In particular, environmental pollution is directly related to the issue of economic justification for secondary and primary metal losses (transfer to finished products, groundwater pollution) [5], changes in the social environment [6].

One more problem is the uneven development of mining enterprises, which is a consequence of technological periods and cycles: design, construction, development of design capacity, reconstruction, production attenuation and enterprise liquidation. Within a separate period, cycles of uneven development are distinguished, which are related to changes in geological conditions, introduction of new technologies and technical devices, limitations of market capacity, accidents and incidents, etc. [7].

Analysis of modern literature revealed another serious problem of mining enterprises lack of autonomy (or competence) among managers making decisions on mining enterprises. S. Prokopenko considers the current situation on the example of a systematic approach to the use of consumables (cutting tools, crowns), as well as other resources in the current mines. Managers are not engaged in calculation and usage efficiency evaluation of spare parts, materials and tools, do not lead the search for economic resources, do not perceive proposed innovations. The crowns tender purchase scheme used by the enterprises reveals not economical products, but the cheapest (which is far from being the same thing). [8].

Speaking about the incomplete list of local problems (micro level) formulated above, we can move to a higher level - meso-level of enterprise activity (directly related to interaction with regions). In our opinion, this level is an important direction in developing the mining enterprise strategy. The choice of managed attenuation strategy must be carried out focusing on aggregate (final) performance indicators. With this, we agree that the very problem of defining these criteria for a mining enterprise may also be the subject of discussion. Partly, we associate the meso-level for the mining enterprise with the economicgeographical zoning, which gives grounds to use the work of M. Kononykhin [9]. In our view, the main resource constraints (opportunities) for the mining enterprise are the resources specified in Table 1. 
Table 1 List of meso-level resources forming the strategic choice of a mining enterprise

\begin{tabular}{|c|c|c|}
\hline $\begin{array}{l}\text { Types } \\
\text { resources }\end{array}$ & Resource names & $\begin{array}{l}\text { Possibility to } \\
\text { change resources } \\
\text { with age }\end{array}$ \\
\hline \multirow[t]{4}{*}{ Organizational } & $\begin{array}{l}\text { Transport and geographical location, i.e. the position } \\
\text { relative to the transport network (considering capacity, } \\
\text { transport capacity, congestion, speed and cost of } \\
\text { transport) }\end{array}$ & $\begin{array}{l}\text { unchanged or } \\
\text { deteriorating }\end{array}$ \\
\hline & $\begin{array}{l}\text { Industrial and geographical - position relative to energy } \\
\text { sources, centers of manufacturing industry and scientific } \\
\text { and technical bases }\end{array}$ & $\begin{array}{ll}\text { unchanged } & \text { or } \\
\text { deteriorating }\end{array}$ \\
\hline & $\begin{array}{l}\text { Availability of qualified managers with industry } \\
\text { knowledge }\end{array}$ & not identified \\
\hline & $\begin{array}{l}\text { Availability of consuming enterprises. It refers to the } \\
\text { involvement of the mining enterprise in the process chain } \\
\text { and its role in it }\end{array}$ & Often improve \\
\hline \multirow[t]{2}{*}{$\begin{array}{l}\text { Physical (by } \\
\text { location) }\end{array}$} & $\begin{array}{l}\text { Natural and climatic }- \text { temperature regime, climatic } \\
\text { features, features of nature of the day surface }\end{array}$ & unchanged \\
\hline & Alternative options for the development of territories & undefined \\
\hline $\begin{array}{l}\text { Natural and } \\
\text { environmental }\end{array}$ & $\begin{array}{l}\text { Availability of tailings and possibility of processing } \\
\text { (discharge) of groundwater }\end{array}$ & tend to get worse \\
\hline Financial & $\begin{array}{l}\text { Market (availability of financial resources sources) }- \\
\text { borrowed funds, equity, funds of FIG (financial-industrial } \\
\text { group) }\end{array}$ & undefined \\
\hline Technological & $\begin{array}{l}\text { Availability of equipment and technological capabilities } \\
\text { to increase technological capacities }\end{array}$ & $\begin{array}{l}\text { unchanged or } \\
\text { deteriorating }\end{array}$ \\
\hline $\begin{array}{ll}\text { Mineral raw } \\
\text { materials }\end{array}$ & $\begin{array}{l}\text { Type (shape) of deposits, mining and geological } \\
\text { conditions and degree of their complication }\end{array}$ & tend to get worse \\
\hline \multirow[t]{2}{*}{ Human } & $\begin{array}{l}\text { Demographic presence of population concentration, labor } \\
\text { resources, scientific and technical personnel at or near the } \\
\text { enterprise }\end{array}$ & tend to get worse \\
\hline & $\begin{array}{l}\text { The presence of social duties at the enterprise and the } \\
\text { extent of its influence on the development of territories. }\end{array}$ & Tend to get worse \\
\hline
\end{tabular}

The issue of integral index remains open. Thus, for a separate mining enterprise, the issue of social responsibility is not determinant, but for the development of the region it is of direct importance. Accordingly, in addition to the direct economic (business) effect of the enterprise itself, it is necessary to consider environmental, demographic and economic consequences of its activities for the region of its location.

Even with the choice of effective measures recommended by modern authors to increase the efficiency of obtaining mineral resources and to maintain the raw materials base of mining enterprises, these problems are still actual. Thus, the following is named among the measures for the rational use of natural resources:

- Increased extraction of mineral resources from subsoil and processing;

- organization of quarry (in-mine) ore pretreatment for enrichment;

- involvement of off-balance reserves both from the subsoil and from the dumps;

- separate mining and processing of ores by type; 
- formation of ore flows of required quality, organization of complex ore processing [10]. With the overall fairness of these measures, their implementation requires costs and normally increases the overall negative impact on the enterprise.

\section{Conclusions}

With modern mining technique with its inherent production organization, it should be understood that productivity growth (with constant geological and edge reserves) leads to accelerating the field processing and reducing labor costs. According to the Russian authors, auxiliary works are currently the determining factor of labor productivity growth and the reduction of labor costs in these works is one of the major problems of the mining industry (the latter is often achieved by outsourcing some functions with a decrease in the amount of social guarantees for workers). The authors also suggest using organizational tools. Thus, domestic researchers offer the use and implementation of combined business schemes (large mining and enrichment and small enterprises, processing secondary products - slams, heap leaching products), which allows to ensure effective involvement in secondary development of man-made mineral resources [11].

However, we think that in the development of a mining enterprise development strategy in the old industrial region it is necessary to comprehensively analyze the system of social indicators (characteristics) of mining enterprises' activities in the current period and in the future considering regional interests. Otherwise, labor productivity growth will only accelerate negative social processes, while reducing the existence of a mining enterprise and reducing the capacity of the region to prepare to this event. The enterprises development in such regions should be built not by increasing labor productivity, but by reducing the production cost — prolonging, but not reducing the term of mining field use. Accordingly, in order to implement such a strategy, a comprehensive strategy for managed attenuation of the mining enterprise must be developed.

\section{References}

1. S. V. Kornilkov, V. D. Kantemirov, Mining journal, 2, 14-20 (2014)

2. S. V. Kornilkov, V. D. Kantemirov, Journal of Higher Education Institutions. Mining journal, 8, 22-28 (2015)

3. O. V. Trifonova, O.Y. Kravets, Management of coal products flows and sustainable operation of unprofitable mines of Ukraine: monograph, National Mining University, 202 (D.: NSU, 2014)

4. A.G. Shpitalnikov, Increase of economic efficiency of production in the mining industry, 175 (Moscow: Nedra, 1970)

5. O. S. Bryukhovetsky, A. G. Sekisov, Ecological and economic model of mining enterprise of recaptured underground ore mass mining, Notes of the Mining Institute (2005

6. V. G. Loginov, M. N. Ignatieva, V. V. Balashenko, Economics of the Region, 14 (3), 896-913 (2018)

7. A. V. Fedash, Methodical Basis of Making Design Decisions on Creation of Flexible Geotechnological Complexes of Mining and Energy Enterprises, 9, (MIAB. 2011)

8. S. A. Prokopenko, Mining industry, 3 (103), 76-80 (2012)

9. M. A. Kononykhin, Mining Information and Analytical Bulletin, 3, 100-102 (2006)

10. S. V. Kornilkov, S. A. Rylkov, V. S. Shemyakin, Problems of subsoil use, 3 (3), 46-54 (2014)

11. O. S. Bryukhovetsky, A. G. Sekisov, S. S. Klimov, Bulletin of higher educational institutions. Geology and exploration, 5, 67-69 (2006) 